\title{
Police and Judicial Cooperation Policy
}

\author{
Stephen Rozée
}

Christian Kaunert

Sarah Léonard

Several major European Union (EU) treaty revisions, as well as the increased political prioritisation of counter-terrorism and combating organised crime in Europe, have led to the development of the Area of Freedom, Security and Justice (AFSJ) into one of the most dynamic fields of European integration (Kaunert et al. 2014). Within the AFSJ, cooperation in police and judicial matters has significantly developed since the late 1990s. This chapter begins by locating the development of police and judicial cooperation into the broader context of the creation and evolution of the AFSJ and its institutional aspects. The following section explores various academic approaches to the study of European police and judicial cooperation. The remainder of the chapter is devoted to examining the main actors and issues in EU police and judicial cooperation in criminal matters.

\section{The development of police and judicial cooperation in the context of the AFSJ}

The Treaty of Maastricht provided the EU with its first formal competences in internal security and justice matters, building significantly on the limited intergovernmental cooperation that had previously existed, such as within the so- 
called 'TREVI' group (Kaunert et al. 2014). Article K.1 of Title VI of the Treaty on European Union (TEU) (1993) set out that '[for] the purpose of achieving the objectives of the Union, in particular the freedom of movement of persons, and without prejudice to the powers of the European Community, Member states shall regard the following areas as matters of common interest (...)'. Those were (1) asylum policy; (2) external border control; (3) immigration (entry, circulation, stay and fight against illegal immigration); (4) fight against drugs and (5) against international crime; (6) judicial cooperation in civil matters and (7) in criminal matters; (8) customs cooperation; and (9) police cooperation. The Treaty of Maastricht placed these matters in the 'third pillar' of Justice and Home Affairs (JHA), alongside the European Community (first pillar) and the Common Foreign and Security Policy (second pillar). As a consequence, these issues continued to be mostly dealt with on an intergovernmental basis, which resulted in only limited policy progress (Geddes 2000: 86; Uçarer 2001: 6; Kaunert et al. 2014).

Under the 1999 Treaty of Amsterdam, JHA policies became re-labelled as the 'Area of Freedom, Security and Justice' (AFSJ). This treaty brought a rise in the prominence of EU justice and internal security cooperation. Where JHA cooperation had concerned 'matters of common interest', which had to be considered as such by Member States '[for] the purposes of achieving the objectives of the Union' (Article K.1 TEU), the realisation of the AFSJ was identified as an objective in its own right (Kaunert et al. 2014). The Treaty of Amsterdam stated that 'the Union's objective shall be to provide citizens with a high level of safety within an area of freedom, security and justice by developing common action among the member states (...)'. Extensive changes were made to the institutional arrangements relating to JHA matters in order to achieve this objective, including the partial 'communitarisation' of 
the third pillar. However, while controls on external borders, asylum, immigration and judicial cooperation on civil matters were transferred to the first pillar, police and judicial cooperation in criminal matters remained in the third pillar (Kaunert et al. 2014).

On 1 December 2009, the Treaty of Lisbon entered into force. The Treaty formally abolished the EU's three-pillar structure, which has had the effect of simplifying the decision-making procedure in the AFSJ. While the 'communautarisation' of criminal justice and policing matters has increased, the inclusion of provisions establishing 'emergency brakes' and 'accelerators' means that it is not fully complete (Kaunert 2010). The EU's objectives for each policy dimension of the AFSJ are set out in Title V of the Treaty on the Functioning of the European Union (TFEU) ('Area of Freedom, Security and Justice') (Kaunert et al. 2014).

\section{Academic approaches to the study of the AFSJ and EU police and judicial} cooperation

The AFSJ has received increasing scholarly attention due to its rapid growth in recent years (Walker 2004; Peers 2006, 2012). Many scholars have claimed that developments in the AFSJ have been driven primarily by concerns about security, rather than freedom and justice, which has led to the adoption by the EU of a range of new policies and instruments relating to police and judicial cooperation (Baldaccini et al. 2007; Balzacq and Carrera 2006; Huysmans 2006; Guild and Geyer 2008; van Munster 2009; Bigo et al. 2010; Kaunert et al. 2014). Concepts and analytical frameworks from Security Studies have been used to examine the development of the EU's approach to its internal security, including 'homeland security' (Kaunert et al. 
2012) and 'comprehensive security' (Kaunert and Zwolski 2013; Rozée 2013). Other academic work has focused on the links between the internal and external dimensions of EU security, in particular highlighting the ways in which the EU has aimed to influence the internal security policies of neighbouring states (Balzacq 2009; Trauner and Carrapiço 2012; Rozée 2015). Within the literature on EU police and judicial cooperation, increasing attention has been given to the EU's counter-terrorism policy (Spence 2007; Eckes 2009; Bures 2011; Argomaniz 2011; Kaunert and Léonard 2011; Léonard and Kaunert 2012; Kaunert et al. 2012; Bossong 2012; MacKenzie et al. 2013; de Londras and Doody 2015).

Other academic contributions can be seen as contributing to the classical debate over the nature of EU integration, between theories that emphasise supranational institutions and those that portray the EU as intergovernmental and dominated by the interests of nations. Neo-functionalism describes European integration as 'the process whereby actors in several distinct national settings are persuaded to shift their loyalties, expectations and political activities towards a new cent[re], whose institutions possess or demand jurisdiction over pre-existing national states' (Haas 1958: 16). According to this view, the 'loyalty' of citizens in a given community can shift towards a new political entity, in particular towards supranational organisations, such as the European Commission (Rosamond 2000: 6568; Kaunert et al. 2012: 6). At the opposite end of the spectrum are those scholars who emphasise the role of national interests in driving the process of European integration and view the EU primarily as an intergovernmental organisation. Moravcsik $(1998,1999)$ has argued that national leaders make decisions in response to constraints and opportunities derived from the economic interests of powerful domestic constituents, as well as the relative power of each state in the international 
system (Kaunert et al. 2012: 6). From this perspective, the purpose of international institutions is to bolster the credibility of interstate commitments (Moravcsik 1998). Supranational institutions, such as the European Commission, are not considered to have significant independent powers in their own right, but are rather viewed as facilitators of the collective will of national governments (Nugent 2006: 553).

This debate over the nature of EU integration has informed the analysis of the EU's security activities and of the development of police and judicial cooperation. It can notably be seen in the scholarly literature on the roles of different actors in the development of the AFSJ, including police and judicial cooperation. From an intergovernmentalist perspective, the process of European integration is dominated by national leaders and national interests, meaning that EU integration occurs because of a change in interests within the Member States or as the result of a grand political bargain (Moravcsik 1998: 18). While the Member States have a central place in the EU policy-making process, several scholars have criticised the fact that Moravcsik's intergovernmentalist view 'assumes national interests to be exogenous of the EU process' (Wincott 1995: 602). Member States continuously interact within the EU system, and national interests and preferences may be shaped by different norms and values (Christiansen 2002, 2008; Christiansen and Reh 2009; Kaunert 2012: 34). In addition, these norms may change over time (Finnemore 1996a, 1996b; Finnemore and Sikkink 1998). Kaunert (2012: 34-35) describes the construction of norms as occurring in several stages. First, actors provide reasons for action. In competition with each other, actors push for their reasons for action to be accepted as a norm. Following this, the norm socialisation stage occurs; a norm will then eventually become the dominant norm. The concept of norms is highly useful for understanding the process of EU policy-making. While national sovereignty remains the prevailing 
norm in the international system, within the EU, this norm is in constant competition with the norm to pool sovereignty at the EU level and thereby move the process of European integration forward.

\section{Actors in EU police and judicial cooperation policy-making}

Under the Treaty of Lisbon, EU police and judicial cooperation measures are adopted according to the ordinary legislative procedure, which has replaced the co-decision procedure. A feature specific to police and judicial cooperation matters is that the Commission shares its power of legislative initiative with the Member States, provided that they represent a quarter of the members of the Council (Article 76 TFEU). The European Parliament is consulted on operational cooperation measures, which are adopted unanimously by the Council. It is also possible for nine or more Member States to work together on the basis of 'enhanced cooperation' if the Council does not reach unanimity; in such cases, the European Council suspends the process in order to seek consensus ('emergency brake' mechanism under Article 87(3) TFEU).

Kaunert (2012: 43) argues that supranational institutions have played a significant role in advancing AFSJ policies. In particular, the European Commission can be viewed as a 'supranational policy entrepreneur'. In other words, it has acted 'to initiate and push for a process of normative change regarding national sovereignty in the ASFJ among EU decision-makers, as well as concrete institutional change' (Kaunert 2012: 35). The policy entrepreneurship of the European Commission began at the policy-making level in the AFSJ with regard to issues such as the European Arrest Warrant (EAW) and the Common European Asylum System (CEAS). The Commission also contributed to a shift in political norms enabling decision-makers to 
consider the 'communitarisation' of the AFSJ through alliances with other EU institutional actors, such as the then European Parliament's Committee on Citizens' Freedoms and Rights, Justice and Home Affairs (LIBE Committee), as well as by gaining the support of civil society groups (Kaunert 2012: 37-43).

Efforts were made by the European Commission to press for a normative change in attitude towards the supranationalisation of the AFSJ during the European Convention debates in 2002-2003 and the subsequent negotiation of the Lisbon Treaty. The Commission can be seen to have acted as a 'first mover' to shape the debate on the future of the AFSJ, prioritising further integration in the ASFJ alongside the adoption of the Charter of Fundamental Rights (Beach 2005: 15; Kaunert 2012: 38). This was notably facilitated by the inclusion of the then Justice and Home Affairs Commissioner Antonio Vitorino as one of the two representatives of the European Commission at the European Convention (Kaunert 2012: 38-39). Going back to the scholarly literature on policy entrepreneurship, Kingdon (1984) suggests that, in a close-knit policy community, a policy entrepreneur can shape the way in which problems are defined. Against this backdrop, Kaunert (2012: 38) argues that commonly held beliefs influence people's ideas and behaviours, and that participants in a policy community interact with each other and are socialised according to the norms that are prevalent in this reference group. In other words, social norms can influence the behaviour of people in a given policy community. It can therefore be concluded that the European Commission has acted as a significant supranational policy entrepreneur in driving forward European integration in the ASFJ.

While it can be argued that institutions matter to the process of European integration in the AFSJ, Member States and their governments also remain of central importance. This can be clearly seen in the ratification stage of any EU treaty, where 
Member States are 'the only game in town' (Kaunert 2012: 44). The case of the Constitutional Treaty aptly illustrates this point. France and the Netherlands rejected this treaty in referenda, whilst the British government subsequently froze its ratification. Furthermore, French President Sarkozy and German Chancellor Merkel were key actors in the subsequent Lisbon Treaty renegotiations, whilst the Irish voted twice before the Lisbon Treaty could be ratified (Kaunert 2012: 44).

\section{Issues and activities in EU police and judicial cooperation in criminal matters}

The remainder of this chapter explores developments in EU police and judicial cooperation in criminal matters and highlights key areas that have received academic attention. Police and judicial cooperation in criminal matters is dealt with in Title V of the TFEU (Chapters I, IV and V). It includes three main elements: cooperation amongst national police forces; cooperation amongst national administrations; and cooperation amongst national judicial authorities.

The beginning of EU police cooperation can be traced back to the so-called 'TREVI' cooperation that started in 1975, whereas EU judicial cooperation in criminal matters formally began with the entry into force of the Treaty of Maastricht in 1993. The Treaty of Amsterdam, which entered into force in 1999, provided significant impetus to the development of EU police and judicial cooperation in criminal matters.

The cornerstone of EU judicial cooperation is the principle of the mutual recognition of judicial decisions. This means that each national judicial authority must recognise decisions made by the judicial authority of another EU country with a minimum of formalities and with very few exceptions. The adoption of this principle has enabled the development of judicial cooperation without first harmonising 
criminal law across the EU, which has been perceived to be difficult given the divergence of national criminal law systems and traditions (Monar 2013: 3). The development of judicial cooperation has also been facilitated by the establishment of the European Judicial Network (EJN), which is a network of national contact points that was established in 1998. The EJN has facilitated direct communication between national authorities at the operational level by fostering direct contacts, disseminating information and supporting bilateral judicial assistance requests (Monar 2013: 3).

A remarkable example of the progress made in the mutual recognition of judicial decisions is the EAW, which is an arrest warrant valid in all EU Member States. Once issued, the EAW requires an EU Member State to arrest a criminal suspect and transfer them to the issuing state, so that this person can be put on trial or complete a detention period (Council of the European Union 2002). The EAW, which has been considered by some as the EU's flagship counter-terrorism measure in the past decade (Argomaniz et al 2015: 199), has reduced the average extradition period of serious crime suspects from more than nine months to 45 days (European Commission 2005). Kaunert (2007: 1-2) has argued that the EAW has significantly changed the system of extradition within EU Member States, changing what was formerly an intergovernmental system based on inter-state relations and extraditions into an inter-judiciary system. This can be viewed as an example of European integration progressing into areas of 'high politics', contrary to what many had expected (Hoffmann 1966).

In addition to the EAW, which has been widely used since its creation, the principle of mutual recognition has also been applied to other types of judicial decisions, such as orders freezing property or evidence (Monar 2013: 340). In 2008, it was also decided to establish a European Evidence Warrant (EEW), which is a 
judicial decision whereby objects, documents and data may be obtained from other EU Member States. Some modest progress has also been made with regard to the harmonisation ('approximation') of national criminal laws following the adoption of the Treaty of Amsterdam. This can be seen in the adoption of a range of EU Framework Decisions concerning various types of criminal activities, including Euro counterfeiting, terrorism, drug trafficking, racism and xenophobia, trafficking in human beings, and child pornography. Harmonisation in these areas has been based upon common core definitions of the constituent elements of criminal acts, as well as common minimum and maximum penalties (Monar 2013: 341).

EU police and judicial cooperation has been significantly fostered by two European agencies, namely the European Agency for Law Enforcement Cooperation, that is, Europol, which was previously known as the European Police Office, and the EU's Judicial Cooperation Unit (Eurojust). As these agencies have come to play a pivotal role in European police and judicial cooperation, the remainder of this chapter focuses on their activities in order to examine the development of European integration in these interconnected policy areas.

\section{Europol}

The EU's law enforcement agency, Europol, mainly aims to improve effectiveness and cooperation among the competent authorities of the EU Member States with regard to preventing and combating terrorism, drug trafficking, and other types of serious crime. Article K.1 of the Treaty of Maastricht foresaw 'the organisation of a Union-wide system for exchanging information within a European Police Office (Europol)'. Delays in the ratification of the Treaty of Maastricht led to the decision to set up a Europol Drugs Unit. This forerunner to Europol operated between 1995 and 
1999. It was replaced by Europol on 1 July 1999, after all EU Member States had ratified the Europol Convention that had been signed in July 1995 (Bures 2008: 501; Kaunert 2010: 653-654). Since 2010, Europol has been a fully-fledged European agency and, as of 2016, has more than 1,000 members of staff working at its headquarters in The Hague (Europol, 2016).

Europol is not an executive police force and therefore has no direct powers to make arrests or launch its own investigations. Instead, it aims to support the law enforcement agencies of the Member States by gathering, analysing and disseminating information and coordinating operations. In addition, experts and analysts from Europol take part in Joint Investigation Teams (JIT's) that investigate criminal cases that occur in EU countries. Furthermore, operational and strategic agreements have been made between Europol and many third states, including Australia, Canada, Croatia, Iceland, Norway, Switzerland, and the United States, as well as several non-EU institutions such as Interpol and the United Nations Office on Drugs and Crime (Kaunert 2010: 655; Europol 2016).

Article 3 of the 1995 Europol Convention laid down the formal activities of Europol as follows: (1) to facilitate the exchange of information between the Member States; (2) to obtain, collate and analyse information and intelligence; (3) to notify the competent authorities of the Member States without delay via the national units referred to in Article 4 of information concerning them and of any connections identified between criminal offences; (4) to aid investigations in the Member States by forwarding all relevant information to the national units; (5) to maintain a computerised system of collected information containing data; (6) to participate in a support capacity in JIT's; and (7) to ask the competent authorities of the Member States concerned to conduct or coordinate investigations in specific cases. A range of 
additional tasks were also defined in Article 3(2) of the Convention, including the provision of strategic intelligence and the production of general situational reports (Rozée et al. 2014).

Europol operates by working closely with the law enforcement agencies of the EU Member States, through the Europol National Units (ENU) and the liaison officers based at the Europol headquarters in The Hague. Each Member State has a designated ENU that is tasked with the liaison between Europol and the national authorities; each national unit seconds at least one liaison officer to Europol who is hosted at the Europol headquarters. The role of the liaison officers is to represent the interests of their national unit in accordance with the national law of the seconding Member State. Europol maintains several major databases as part of the Europol Computer System; these databases are used for providing support through intelligence analysis to investigations being carried out by the competent authorities of the Member States (Europol 2006: 2-6; Rozée et al. 2014). These include the European Information System (EIS), which contains data on persons suspected of serious criminality under Europol's remit; the Analysis Work Files (AWFs), which are created by Europol's experts as well as the national experts seconded to Europol; and an index system containing extensive records of the information held in the EIS and the AWFs (Occhipinti 2003: 61, Kaunert 2010: 655).

Europol has gained significantly increased powers since the ratification of the Europol Convention. This has been particularly evident in the area of counterterrorism, where Europol saw an expansion of its mandate after the 9/11 terrorist attacks in New York. It was notably decided to establish a Counter-Terrorist Task Force (CTTF), an operational centre comprising national liaison officers from police and intelligence service and offering 24-hour support for the exchange of information 
(Rozée et al. 2014). Following the 2004 terrorist attacks in Madrid, the CTTF received a strengthened mandate, which included the collection of all relevant information and intelligence concerning the current terrorist threat in the EU; the analysis of the collected information and the undertaking of operational and strategic analysis; and the formulation of a threat assessment, including targets, modus operandi, and security consequences. These threat assessment reports were amongst the most important outputs of the CTTF and notably included assessments on the financing of terrorism and on terrorist movements in Europe (Rozée et al. 2014). In addition, Europol gained the competence to request that the law enforcement agencies of EU Member States launch investigations and share information with the US Federal Bureau of Investigation (FBI), as well as other third parties (Kaunert 2010: 656). In January 2016, Europol launched the European Counter Terrorism Centre (ECTC), which is both a hub of counter-terrorism expertise and an operations centre.

Another area where Europol has become increasingly active is cyber-crime, as evidenced by the establishment of the European Cybercrime Centre (EC3) within the agency in 2013. EC3 aims to strengthen the law enforcement response to cybercrime in the EU, thereby contributing to the protection of European citizens, businesses and governments from online crime. At the time of writing, the work of the EC3 is structured around three themes: strategy, forensic expertise, and operations. Finally, Europol has also become increasingly active in the fight against migrant smuggling, which has resulted in the establishment of a third centre within the agency, namely the European Migrant Smuggling Centre (EMSC). This centre was established in February 2016 as a response to the growth of criminal organisations involved in migrant smuggling. The EMSC mainly aims to help Member States improve information exchange and the coordination of their operations against migrant 
smuggling. It supports cooperation not only amongst the Member States, but also between them and international organisations, national stakeholders and other European agencies.

Nevertheless, despite the significant growth in its activities over the last few years, Europol has encountered several obstacles and challenges that have hampered its development and effectiveness (Bures 2008; Rozée et al. 2014). Firstly, due to a lack of trust, the law enforcement agencies of the Member States have sometimes been reluctant to provide Europol with information or to make use of the support mechanisms that it offers. This reluctance also partly stems from the existence of long-standing informal bilateral or multilateral arrangements amongst some law enforcement agencies in the EU for the purposes of information-sharing and practical coordination, which may be seen as more reliable, more flexible and less bureaucratic than operating through Europol (Bures 2008). Another issue is that Europol was formed by top-down political decisions from the EU's political and legislative bodies; police professionals did not create it through a bottom-up process. This may also offer some explanation as to why the law enforcement agencies of the Member States have been at times reluctant to work with Europol and to use Europol mechanisms (Bures 2008). A final difficulty for Europol has been the lack of supranational powers provided to it under EU treaties (Bures 2008, Kaunert 2010).

Finally, it is noteworthy that police cooperation in the EU has also been supported by the activities of another European agency, the European Union Agency for Law Enforcement Training (CEPOL). This agency, which is now seated in Budapest, supports cooperation and knowledge-sharing among law enforcement officials of the EU Member States and to some extent of third countries on key security issues in the EU. 


\section{Eurojust}

The Presidency Conclusions of the Tampere European Council in October 1999 had called for the establishment of a 'unit (EUROJUST) (...) composed of national prosecutors, magistrates, or police officers of equivalent competence, detached from each Member State according to its legal system' in order to strengthen the fight against serious organised crime. It was envisaged to task Eurojust with facilitating the coordination of national prosecuting authorities and supporting criminal investigations in organised crime cases, notably based on Europol's analysis, as well as co-operating closely with the European Judicial Network. At the initiative of Portugal, Belgium, France, and Sweden, it was decided in 2000 to create a Provisional Judicial Cooperation Unit ('pro-Eurojust'), which gave way to Eurojust after the adoption of Decision 2002/187/JHA (Luchtman and Vervaele 2014: 134-135; Weyembergh 2013: 177-178). The main aim of policy-makers was to establish the equivalent of Europol for judicial cooperation in criminal matters, by supporting cooperation amongst the prosecution authorities of the EU Member States (Labayle and Nilsson 2010: 195-196).

The support offered by Eurojust has particularly focused on facilitating the execution of international mutual legal assistance and the implementation of extradition requests. Eurojust deals with the same categories of crimes as Europol, including terrorism, drug trafficking, trafficking in human beings, counterfeiting, money laundering, computer crime, crime against property or public goods including fraud and corruption, criminal offences affecting the European Union's financial interests, environmental crime and participation in a criminal organisation (Eurojust 2016). However, whereas the development of Europol was not without controversies 
notably regarding the issue of its accountability, the establishment and the evolution of Eurojust have been rather uncontroversial (Busuioc and Groenleer 2013: 286).

In addition, Eurojust has grown beyond the purely supportive role for cooperation amongst national prosecution authorities that had been originally foreseen and has acquired a more operational role than Europol (Monar 2013: 343-344). For example, the Decision of 16 December 2008 on the strengthening of Eurojust extended the duty of Member States to justify refusals to follow Eurojust requests (Weyembergh 2013: 178). Also, the types of requests that Eurojust can make go beyond merely supporting cooperation (Monar 2013: 343). They include asking the competent authorities of a Member State to undertake an investigation or the prosecution of specific acts, setting up a Joint Investigation Team (JIT), taking special investigative measures, as well as taking any other measure justified for the investigation or prosecution (Council of the European Union 2009; Monar 2013: $343)$.

Nevertheless, at the time of writing, Eurojust remains 'a mediator, a facilitator, without any decision-making powers vis-à-vis national authorities' (Weyembergh 2013: 178). It does not possess any binding powers over the EU Member States. This means that, if national authorities refuse to comply with its recommendations or requests, Eurojust can do little else than recording such instances in its reports (Weyembergh 2013: 178). This could change in the future as the TFEU contains provisions that could have an important impact on judicial cooperation in criminal matters and the development of Eurojust. Article 85 of the TFEU foresees the granting of binding powers to Eurojust vis-à-vis national authorities, whilst Article 86 allows for the establishment of a European Public Prosecutor's Office (EPPO) 'from Eurojust'. According to Monar (2013: 351), Article 86 of the TFEU 'can be 
considered one of the most radical and innovative EU treaty provisions ever introduced: It means nothing less than the possibility of establishing a central prosecution authority whose powers would extend to all participating member states and all individuals within their jurisdiction.' This is because the Treaty of Lisbon has awarded the EPPO significant powers, including the responsibility for 'investigating, prosecuting and bringing to judgment, where appropriate in liaison with Europol, the perpetrators of, and accomplices in, offences against the Union's financial interests'. In addition, it stipulates that the EPPO 'shall exercise the functions of prosecutor in the competent courts of the Member States in relation to such offences' (Article 86(2) TFEU).

Against this backdrop, the European Commission tabled two legislative proposals on the basis of Articles 85 and 86 TFEU in July 2013. The proposal for a Regulation on Eurojust aims to improve its governance, operational effectiveness and accountability framework and, ultimately, to strengthen the operational work of Eurojust in the fight against cross-border crime. As for the proposal for a Regulation on the establishment of an EPPO, it seeks to create a novel European body that would investigate, prosecute and bring to judgement perpetrators of crimes that affect the financial interests of the EU (i.e. the so-called 'PIF crimes'). However, negotiations on these Regulations in the Council and the European Parliament have proven slow and arduous. First of all, some Member States, including Austria, Finland, Sweden and France, have expressed some concerns over the establishment of the EPPO (Monar 2013: 353; European Parliament 2016). In addition, the question of how to interpret the idea of establishing the EPPO 'from Eurojust' has been particularly controversial. As outlined by Monar, this can be interpreted in three different ways: (1) the gradual evolution of Eurojust into the EPPO, which would eventually replace 
Eurojust, (2) the establishment of the EPPO as a permanent component of Eurojust, or (3) the gradual growth of the EPPO leading to its eventual separation from Eurojust to form a distinct body. This debate is still far from being settled with the consequence that the proposed EPPO Regulation has not yet been adopted. The disagreements over the EPPO have also had a significant impact upon the negotiations over the proposed Eurojust Regulation. In March 2015, the Council reached a general approach, with the exception of the provisions concerning the relationship between Eurojust and the EPPO. However, the European Parliament decided to withhold its position, arguing that clarification on the relations between the EPPO and Eurojust was first needed. Despite these delays and challenges, the European Commission has confirmed its continued commitment to establishing the EPPO (European Commission 2013; European Parliament 2016). Nevertheless, given the watershed that the establishment of the EPPO would represent, it is likely that considerably more time will be needed for the negotiations and that the end result might be the establishment of the EPPO with a limited number of EU Member States on the basis of the 'enhanced cooperation' mechanism.

\section{Conclusion}

EU police and judicial cooperation in criminal matters has seen remarkable developments in the last few years. National police forces, administrations and judicial authorities are increasingly cooperating across the EU. This has been significantly facilitated by the European agencies active in this policy domain, mainly Europol and Eurojust. Some EU measures have also had a critical impact, in particular the EAW. However, various obstacles, such as mistrust or the preference for bilateral arrangements, have remained, which have hindered the development of 
EU police and judicial cooperation in criminal matters. One can nevertheless expect to see further progress being made in European police and judicial cooperation in criminal matters in the next few years, as EU Member States seek to address transnational security threats, such as terrorism and cyber-crime, that affect a growing number of them.

\section{References}

Argomaniz, J. (2011) The EU and Counter-terrorism: Politics, Polity and Policies after 9/11. London: Routledge.

Argomaniz, J., Bures, O. and Kaunert, C. (2015) 'A Decade of EU Counter-Terrorism and Intelligence: A Critical Assessment', Intelligence and National Security, 30(2-3): 191-206.

Baldaccini, A., Guild, E. and Toner, H., eds (2007) Whose Freedom, Security and Justice? EC Immigration and Asylum Law and Policy. Oxford: Hart.

Balzacq, T., ed. (2009) The External Dimension of EU Justice and Home Affairs: Governance, Neighbours, Security. Basingstoke: Palgrave Macmillan.

Bigo, D. et al., eds (2010) Europe's 21st Century Challenge: Delivering Liberty. Farnham: Ashgate.

Bossong, R. (2012) The Evolution of EU Counter-terrorism: European Security Policy after 9/11. London: Routledge.

Bures, O. (2008) 'Europol's Fledgling Counterterrorism Role,' Terrorism and Political Violence, 20(4): 498-517.

Bures, O. (2011) EU Counterterrorism Policy: A Paper Tiger? Farnham: Ashgate.

Busuioc, M. and Groenleer, M. (2013) 'Beyond Design: The Evolution of Europol and Eurojust', Perspectives on European Politics and Society, 14(3): 285-304.

Christiansen, T. (2002) 'The Role of Supranational Actors in EU Treaty Reform', Journal of European Public Policy, 9(1): 33-53.

Christiansen, T. (2008) 'The EU Treaty Reform Since 2000: The Highs and Lows Of Constitutionalising The European Union', EIPAscope, 2008/1: 39-44.

Christiansen, T. and Reh, C. (2009) Constitutionalizing the European Union. Basingstoke: Palgrave Macmillan. 
Council of the European Union (2002) 'Council Framework Decision of 13 June 2002 on the European arrest warrant and the surrender procedures between Member States', 2002/584/JHA. Brussels: Council of the European Union.

Council of the European Union (2009) 'Council Decision on the strengthening of Eurojust and amending Council Decision 2002/187/JHA setting up Eurojust with a view to reinforcing the fight against serious crime (consolidated version - not published in the Official Journal)', 5347/3/09 REV 3,15 July 2009. Brussels: Council of the European Union.

Council of the European Union (2012) 'Europol Work Programme 2013', 12667/12, 17 July 2012. Brussels: Council of the European Union.

De Londras, F. and Doody, J., eds (2015) The Impact, Legitimacy and Effectiveness of EU Counter-Terrorism. London: Routledge.

Eckes, C. (2009) EU Counter-Terrorist Policies and Fundamental Rights: The Case of Individual Sanctions. Oxford: Oxford University Press.

Eurojust (2016) 'Missions and Tasks', available at: http://www.eurojust.europa.eu/about/background/Pages/mission-tasks.aspx [Last accessed on 04 December 2016].

European Commission (2005) 'Commission Evaluation Report: The European Arrest Warrant Has Broadly Achieved Its Objectives’, Memo/05/58, 23 February 2005. Brussels: European Commission.

European Commission (2013) 'Protecting taxpayers' money against fraud: Commission proposes European Public Prosecutor's Office and reinforces OLAF procedural guarantees'. Brussels: European Commission. Available at: http://europa.eu/rapid/press-release_IP-13-709_en.htm [Last accessed on 4 December 2016].

European Parliament (2016) 'Towards a European Public Prosecutor's Office (EPPO)', PE 571.399. Brussels: European Parliament. Available at: http://www.statewatch.org/news/2016/nov/ep-study-eppo.pdf [Last accessed on 4 December 2016].

Europol (2012) 'About Europol'. The Hague: Europol. Available at: https://www.europol.europa.eu/about-europol [Last accessed on 4 December 2016].

Finnemore, M. (1996a) National Interest in International Society. Ithaca, NY: Cornell University Press.

Finnemore, M. (1996b) 'Norms, Culture and World Politics: Insights from Sociology's Institutionalism', International Organization, 50(2): 325-48.

Finnemore, M. and Sikkink, K. (1998) 'International Norm Dynamics and Political Change’. International Organization, 52(4): 887-917. 
Geddes, A. (2000) Immigration and European Integration: Towards Fortress Europe? Manchester: Manchester University Press.

Guild, E. and Geyer, F., eds (2008) Security versus Justice? Police and Judicial Cooperation in the European Union. Aldershot: Ashgate.

Haas, E.B. (1958) The Uniting of Europe: Political, Social and Economic Forces 1950-57. Stanford, CA: Stanford University Press.

Hoffmann, S. (1966) 'Obstinate or Obsolete? The Fate of the Nation-State and the Case of Western Europe,' Daedalus, 95(3): 862-915.

House of Lords European Union Committee (2008) Europol: Coordinating the Fight against Serious and Organised Crime, Twenty-Ninth Report of Session 2007-08, HL Paper 183. London: The Stationery Office.

Huysmans, J. (2006) The Politics of Insecurity: Fear, Migration and Asylum in the European Union. London: Routledge.

Kaunert, C. (2005) 'The Area of Freedom, Security and Justice: The Construction of a "European public order", European Security, 14(4): 459-483.

Kaunert, C. (2007) "'Without the Power of Purse or Sword": The European Arrest Warrant and the role of the Commission', Journal of European Integration, 29(4): 387-404.

Kaunert, C. (2010a) 'The External Dimension of EU Counterterrorism Relations: Competences, Interests, and Institutions', Terrorism and Political Violence, 22(1): 4161 .

Kaunert, C. (2010b) 'Europol and EU Counterterrorism: International Security Actorness in the External Dimension', Studies in Conflict \& Terrorism, 33(7): 652671.

Kaunert, C. (2010c) European Internal Security: Towards Supranational Governance in the Area of Freedom, Security and Justice? Manchester: Manchester University Press.

Kaunert, C. and Della Giovanna, M. (2010) 'Post-9/11 EU Counter-terrorist Financing Cooperation: Differentiating Supranational Policy Entrepreneurship by the Commission and the Council Secretariat', European Security, 19(2): 275-295.

Kaunert, C., and Léonard, S. (2011) 'EU counterterrorism and the European Neighbourhood Policy: An Appraisal of the Southern Dimension', Terrorism and Political Violence, 23(2): 286-309.

Kaunert, C., Léonard, S. and MacKenzie, A. (2012) 'The Social Construction of an EU Interest in Counter-terrorism: US Influence and Internal Struggles in the Cases of SWIFT and PNR', European Security, 21(4): 474-496. 
Kaunert, C., Léonard, S. and Pawlak, P., eds (2012) European Homeland Security: A European Strategy in the Making? London: Routledge.

Kaunert, C. and Zwolski, K. (2013) The EU as a Global Security Actor: A Comprehensive Analysis across CFSP and JHA. Basingstoke: Palgrave Macmillan.

Kaunert, C., S. Leonard, H. Carrapiço and S. Rozée (2014) 'Justice and Home Affairs and Scotland: Between the UK's Opt-out Debates and the Scottish Independence Referendum', European Security, 23(3): 344-363.

Kingdon, J.W. (1984) Agenda, Alternatives, and Public Policies. Boston: Little, Brown, \& Co.

Labayle, M. and Nilsson, H. (2010) 'The Role and Organisation of Eurojust: Added Value for Judicial Cooperation in Criminal Matters', in Monar, J., ed. The Institutional Dimension of the European Union's Area of Freedom, Security and Justice. Brussels: PIE-Peter Lang, 195-215.

MacKenzie, A., Kaunert, C. and Léonard, S. (2013) 'EU Counterterrorism and the Southern Mediterranean Countries after the Arab Spring: New Potential for Cooperation?' Democracy and Security, 9(1-2): 137-156.

Monar, J. (2013) 'Eurojust and the European Public Prosecutor Perspective: From Cooperation to Integration in EU Criminal Justice?', Perspectives on European Politics and Society, 14(3): 339-356.

Moravcsik, A. (1998) The Choice for Europe: Social Purpose and State Power from Messina to Maastricht. Ithaca, NY: Cornell University Press.

Moravcsik, A. (1999) 'A New Statecraft? Supranational Entrepreneurs and International Cooperation', International Organization, 53(2): 267-306.

Nugent, N. (2006) The Government and Politics of the European Union. Basingstoke: Palgrave Macmillan.

Peers, S. (2006) EU Justice and Home Affairs Law, $2^{\text {nd }}$ edition. Oxford: Oxford University Press.

Peers, S. (2012) EU Justice and Home Affairs Law, $3^{\text {rd }}$ edition. Oxford: Oxford University Press.

Occhipinti, J. (2003) The Politics of EU Police Cooperation: Towards a European FBI? Boulder, CO: Lynne Rienner.

Rosamond, B. (1995) Theories of European Integration. Basingstoke: Macmillan.

Rozée S., C. Kaunert and S. Léonard (2013) 'Is Europol a Comprehensive Policing Actor?' Perspectives on European Politics and Society, 14(3): 372-387.

Rozée S. (2015) 'EULEX's Order-Maintenance Role in Kosovo: The EU as an 
Increasingly Comprehensive Policing Actor?', European Foreign Affairs Review, 20(1): 97-114.

Spence, D., ed. (2007) The European Union and Terrorism. London: John Harper.

Trauner, F. and Carrapiço, H. (2012) The External Dimension of EU Justice and Home Affairs after the Lisbon Treaty: Analysing the Dynamics of Expansion and Diversification. Special Issue of European Foreign Affairs Review, 17 (2/1): 1-162.

Uçarer, E. (2001) 'From the Sidelines to Centre Stage: Sidekick No More? The European Commission in Justice and Home Affairs', European Integration Online Papers (EIoP), 5(5): 1-25.

Van Munster, R. (2009) Securitizing Immigration: The Politics of Risk in the EU. Basingstoke: Palgrave Macmillan.

Walker, N. (2004) Europe's Area of Freedom, Security and Justice. Oxford: Oxford University Press.

Weyembergh, A. (2013) 'Coordination and Initiation of Investigations and Prosecutions through Eurojust', ERA Forum, 14(2): 177-186.

Wincott, D. (1995) 'Institutional Interaction and European Integration: Towards an Everyday Critique of Liberal Intergovernmentalism', Journal of Common Market Studies, 33(4): 597-609. 